\title{
Study of the effect of photooxidative processes on the surface morphology and physico-mechanical characteristics of biodegradable materials based on secondary polypropylene and chalk additives
}

\author{
R. B. Salikhov ${ }^{\dagger}$, M. V. Bazunova, T. R. Salikhov, A. A. Bazunova, V.P. Zakharov \\ ${ }^{\dagger}$ salikhovrb@yandex.ru
}

Bashkir State University, 32 Zaki Validi St., Ufa, 450076, Russia

\begin{abstract}
When processing and operating polymer materials under the influence of environmental factors (ultraviolet radiation, moisture, oxygen, ozone, etc.), a change in their properties is often observed. This research is devoted to the study of the effect of chalk additives on morphology and topography, as well as the physical and mechanical properties of samples based on recycled polypropylene raw materials after exposure to UV radiation in air. In order to confirm the occurrence of photo oxidative processes, the data of two methods were used: modified iodometric analysis and IR spectroscopy. The physical and mechanical properties of polymer composites before and after photo aging were determined on standard $1 \mathrm{~mm}$ thick blades. To study the surface changes of experimental polymer composites under the influence of ultraviolet radiation, atomic force microscopy was used. The result of the experiment is the proof that the chalk additive interferes with the intensive course of photo-oxidative degradation. In general, the introduction of a chalk additive in a small amount (2 to 10 weight parts) allows maintaining the strength characteristics of composites based on recycled polypropylene raw materials after exposure to UV radiation in air, probably because of crosslinking of macromolecules due to the intermolecular interaction of hydro peroxide groups accumulated by the polymer, as well as involving only surface layers of composite samples in the photo oxidation process. Moreover, the analysis of AFM images of samples subjected to ultraviolet irradiation for 18 hours shows that the surface becomes smoother. This is confirmed by the calculation of the root mean square roughness and the maximum height of the roughness. Further irradiation for additional 18 hours leads to an increase in roughness, which indicates a change in the supra molecular structure in the surface layers of polypropylene as a result of photo oxidative transformations. Therefore, from the obtained composites, one can expect the maintenance of operational characteristics during the period of consumption, followed by decomposition under the influence of environmental factors.
\end{abstract}

Keywords: photodegradation, polymers, atomic force microscopy.

УДК: 544.77, 661.18

\section{Изучение влияния фотоокислительных процессов} на морфологию поверхности и физико-механические характеристики биоразлагаемых материалов на основе вторичного полипропилена и меловой добавки

Салихов Р.Б.†, Базунова М. В., Салихов Т. Р., Базунова А. А., Захаров В.П.

Башкирский государственный университет, ул. Заки Валиди, 32, Уфа, 450076, Россия

При переработке и эксплуатации полимерных материалов под действием факторов внешней среды (ультрафиолетовое излучение, влага, кислород, озон и т. д.) достаточно часто наблюдается изменении их свойств. Данное исследование посвящено изучению влияния меловой добавки на морфологию и топографию, а также физико-механические свойства материалов на основе вторичного полипропиленового сырья после воздействия УФ-излучения на воздухе. С целью подтверждения протекания фотоокислительных процессов использованы данные двух методов: модифици- 
рованного йодометрического анализа и ИК-спектроскопии. Физико-механические свойства полимерных композитов до и после фотостарения определяли на стандартных лопатках толщиной 1 мм. Для исследования изменения поверхности экспериментальных полимерных композитов под действием ультрафиолетового излучения использовался метод атомно-силовой микроскопии. Результатом эксперимента является доказательство того, что меловая добавка препятствует интенсивному протеканию фотоокислительной деструкции. В целом, введение меловой добавки в небольшом количестве (2-10 массовых частей) позволяет сохранить практически неизменными прочностные показатели композитов на основе вторичного полипропиленового сырья после воздействия УФ облучения на воздухе, вероятно, вследствие сшивки макромолекул за счёт межмолекулярного взаимодействия гидропероксидных групп, накопленных полимером, а также вовлечением в процесс фотоокисления лишь поверхностных слоёв образцов композитов. При этом анализ АСМ изображений образцов, подвергнутых ультрафиолетовому облучению в течение 18 часов показывает, что поверхность становится более сглаженной. Это подтверждается и расчетами среднеквадратичной шероховатости и максимальной высоты неровности. Дальнейшее облучение в течение дополнительных 18 часов приводит к увеличению шероховатости, что свидетельствует об изменении надмолекулярной структуры в поверхностных слоях полипропилена в результате фотоокислительных превращений. Следовательно, от полученных композитов можно ожидать сохранения эксплуатационных характеристик в течение периода потребления с последующим разложением под действием факторов окружающей среды.

Ключевые слова: фотодеградация, полимеры, атомно-силовая микроскопия.

\section{Introduction}

Currently, a new approach to the development of polymer materials is being formed, consisting in the need to obtain polymers that retain performance only during the consumption period, and then experience the decomposition process under the influence of environmental factors [1-2], This approach should be applied to polymer devices and products, both in electronic and in ordinary household sphere [3-5].

When processing and operating polymer materials under the influence of environmental factors (ultraviolet radiation, moisture, oxygen, ozone, etc.), a change in their properties is often observed. Such phenomena are commonly called "aging" of polymeric material $[6,7]$.

Thermoplastics, which include many poly olefins, are materials that are in the glassy or crystalline state during operation, and in the viscous flowing state during molding. They are subject to thermal, thermooxidative and, especially, light (photooxidative) aging $[8,9]$.

As a result of filling poly olefins, including polypropylene (PP), composite materials are obtained, the main physical and mechanical properties of which differ significantly from the properties of the matrix. First of all, the filler is introduced in order to strengthen the matrix, the mechanism of which depends on the type of filler (dispersed, fibrous, woven), their own properties and the chemical nature of the surface. Under the influence of the filler, there are also changes in the thermal, electrical, thermo physical, fractional and other properties of the material [10-13]. The most common type of filler in polymer composite materials is dispersed fillers. Calcium carbonate is one of the cheapest and most common types of particulate fillers. The advantages of this filler include white color, a wide range of possible particle sizes, and stability of properties over a wide temperature range [14].

With the absorption of oxygen and exposure to UV radiation, the molecular structure of the polymer changes, which leads to typical manifestations of aging: cracking, migration, discoloration and mechanical properties. Due to the limited ability of UV radiation to penetrate and oxygen diffusion, the degree of photo oxidation of PP decreases as it moves deeper into the surface of the material $[8,15]$. Thus, damage caused by ultraviolet radiation as a result of embrittlement is greatest in the surface layer, where micro cracks form. Therefore, a change in the surface topography of PP-based composite materials is one of the indicators of their photo degradation.

The aim of this work was to study the effect of chalk additives on morphology and topography, as well as to study the physic mechanical properties of materials based on secondary polypropylene raw materials after exposure to UV radiation in air. To achieve this goal, measurements were carried out using iodometric analysis, IR spectroscopy and atomic force microscopy. In addition, we studied the changes in the physic mechanical properties (elastic modulus, breaking stress) of composites based on secondary PP filled with chalk, exposed to UV radiation in air.

\section{Experimental part}

The samples for the studies were prepared based on the following types of raw materials:

1. Recycled PP, corresponding to PP brand "PP 350 white Masterbach 22", which is crushed material from substandard products produced by injection molding in the technological production of ZPI Alternative LLC (Oktyabrsky, Russia).

2. Chalk additive A-LENV3PP-284 manufactured by Aleko-Polymers LLC

The dosage of the chalk additive was calculated in weight parts (wt.pts.) per 100 parts by weight PP.

Obtaining polymer composite materials was carried out in the form of standard blades according to GOST 11262-80, "Plastics. Tensile test method" (sample type No. 5) by injection molding on a Babyplast 6/10P injection molding machine: temperatures in zones $\mathrm{H} 1230^{\circ} \mathrm{C}, \mathrm{H} 2235^{\circ} \mathrm{C}, \mathrm{H} 3220^{\circ} \mathrm{C}$, injection pressure $20 \mathrm{bar}$, injection speed $30 \%$, closing force 35 bar; the cooling water supply temperature of the moving and non-moving parts is $12^{\circ} \mathrm{C}$; sample cooling time $10 \mathrm{~s}$.

To reduce the age of photoaging, the accelerated climatic aging was applied under laboratory conditions using a 
QUV climatic chamber Q-Lab (Ohio, USA). The radiation intensity is $0.89 \mathrm{~W} / \mathrm{m}^{2}$ at $340 \mathrm{~nm}$, the temperature is $450^{\circ} \mathrm{C}$, the radiation duration is $18 \mathrm{~h}$ or $36 \mathrm{~h}$.

In order to confirm the occurrence of photo oxidation processes, the data of two methods were used: modified iodometric analysis (to confirm the presence of hydro peroxide and peroxide groups in aged samples) and IR spectroscopy (to confirm the presence of decomposition products of hydro peroxide and peroxide groups - carbonylcontaining groups).

The method of iodometric analysis consists in the restoration of the group with an iodide ion, followed by titration of the extracted iodine with an aqueous solution of sodium thiosulfate:

$$
\begin{gathered}
\mathrm{R}^{1}-\mathrm{O}-\mathrm{O}-\mathrm{R}^{2}+2 \mathrm{I}-+2 \mathrm{H}+\rightarrow \mathrm{R}^{1}-\mathrm{OH}+\mathrm{I}_{2}+\mathrm{R}^{2}-\mathrm{OH} \\
\mathrm{I}_{2}+2 \mathrm{Na}_{2} \mathrm{~S}_{2} \mathrm{O}_{3}=2 \mathrm{NaI}+\mathrm{Na}_{2} \mathrm{~S}_{4} \mathrm{O}_{6}
\end{gathered}
$$

Prior to the iodometric analysis, the samples of the composites were crushed by high-temperature shear grinding in an extrusion-type apparatus with a screw diameter of $32 \mathrm{~mm}$ at a temperature of $130^{\circ} \mathrm{C}$. The particle size of the obtained powders is from 80 to $200 \mathrm{~nm}$.

The analysis was carried out in accordance with the following procedure:

A calibration graph of the dependence of optical density on the concentration of iodine solution in the presence of acetic acid at $\lambda=490 \mathrm{~nm}$ was preliminary constructed. Precisely $0.1 \mathrm{~g}$ of powdered raw material was weighed, $10 \mathrm{ml}$ of isopropyl alcohol, $2.5 \mathrm{ml}$ of glacial acetic acid, $2.5 \mathrm{ml}$ of a saturated solution of $\mathrm{NaI}$ in isopropanol were added, purged with carbon dioxide for 3 minutes and heated in a water bath for 10 minutes at $80^{\circ} \mathrm{C}$. After cooling, the solution was drained and the optical density of the solution was measured on a KFK-2MP concentration photocolorimeter at a wavelength of $\lambda=490 \mathrm{~nm}$ at $T=25^{\circ} \mathrm{C}$. Using a calibration graph, the concentration of iodine was determined from the optical density value, which corresponds to the concentration of peroxide or hydroperoxide groups in the test sample.

The arithmetic average of the results of five parallel experiments, the difference between which did not exceed $5 \%$, was taken as the result of iodometric analysis.

The IR spectra of pressed plates of composites $1 \mathrm{~mm}$ thick were recorded on a Fourier transform infrared spectrophotometer with a special attachment for recording the specular and diffuse reflection spectra, the spectrum of impaired total internal reflection of the Shimadzu FTIR-8400S.
The physical and mechanical properties of polymer composites before and after photo aging were determined on standard $1 \mathrm{~mm}$ thick blades. The elastic modulus, tensile stress and tensile elongation were determined according to GOST $11262-80$ on a Shimadzu AGS-X tensile testing machine (Japan) at a temperature of $20^{\circ} \mathrm{C}$ and a moving gripping speed of a tensile testing machine of $1 \mathrm{~mm} / \mathrm{min}$.

To study the surface morphology of recycled polymer raw materials filled with natural components depending on the composition, an NT-MDT scanning probe microscope was used.

\section{Discussion of results}

One of the main causes of the aging process of polymer materials is the ultraviolet (UV) radiation of the sun. It initiates and accelerates such irreversible chemical reactions as the splitting and cross-linking reactions in polymer molecules. In this case, not only the appearance changes, but also a negative effect on the mechanical and physical properties is exerted. To compare the degree of aging under the influence of UV radiation and oxygen in the air for composites based on recycled PP and chalk additives, IR spectroscopy and modified iodometric analysis were used in this work.

The results of iodometric analysis are presented in Table 1.

As follows from the data given in the table, the content of peroxide and hydro peroxide groups in samples of composite materials based on recycled polypropylene raw materials in the presence of chalk additives even after $36 \mathrm{~h}$ of contacting materials with UV radiation in air is insignificant and is in the range of $0.560 \cdot 10^{-4}-0.501 \cdot 10^{-4} \mathrm{~mol} / \mathrm{g}$, which indicates a slight intensity of the course of photo-oxidative transformations. The results of iodometric analysis are consistent with the data of IR spectra.

When comparing the IR spectra of samples of recycled polypropylene and samples of composites recycled PP and chalk after $36 \mathrm{~h}$ of exposure to UV radiation in air, it was found that in the samples of composites, in addition to the absorption bands characteristic of methyl, methylene and vinylidene groups, a band is present in the spectra of these samples at $1689 \mathrm{~cm}^{-1}$, characteristic of carbonyl conjugated to a double carbon-carbon bond, which may be due to the photo-oxidative degradation under the influence of UV radiation. These bands are observed only in the IR spectra of composites with a minimum content of chalk additives $2-5$ wt. pts. Consequently, the chalk additive partly impedes

Table 1. The concentration of hydroperoxide and peroxide groups in samples of composite materials based on recycled PP and chalk additives after exposure to UV radiation in air for $18 \mathrm{~h}$ and $36 \mathrm{~h}$.

\begin{tabular}{|c|c|c|c|c|}
\hline No. & Polymer matrix & $\begin{array}{c}\text { The content of chalk } \\
\text { additives, wt.pts. }\end{array}$ & $\begin{array}{c}\text { The concentration of hydroperoxide and peroxide groups after } \\
\text { contact with UV radiation in air, C } \cdot 10^{-4} \mathrm{~mol} / \mathrm{g}\end{array}$ \\
\hline 1 & recycled PP & - & 0.456 & 0.512 \\
\hline 2 & recycled PP & 2 & 0.435 & 0.501 \\
\hline 3 & recycled PP & 5 & 0.520 & 0.530 \\
\hline 4 & recycled PP & 10 & 0.535 & 0.560 \\
\hline 5 & recycled PP & 30 & 0.109 & 0.214 \\
\hline 6 & recycled PP & 50 & 0.100 & 0.197 \\
\hline
\end{tabular}


the course of photo-oxidative transformations. These facts can be explained by the likely ability of calcium carbonate to act as a "trap" for free radicals and inhibit the process of photo oxidation which occurs by a radical-chain mechanism. Also, the development of processes of possible photo degradation of the polymer can be judged by a change in the structure of the surface subjected to UV irradiation. To study the surface changes of experimental polymer composites under the influence of ultraviolet radiation, atomic force microscopy was used.

Atomic force microscopy (AFM) is successfully used in materials science to study the morphology and local physical and mechanical properties of a material at the nano structured level (i.e., at a scale where effects related to the molecular features of the substance must already be taken into account, although the material itself can still be considered a continuous medium). Today it is already well known that the physical properties of nano particles and clusters, determined by their extremely high specific surface area, can very significantly differ from macroscopic characteristics.

The results of studies of samples of recycled PP and chalk with a different composite composition before and after treatment with UV radiation in air for 18 and $36 \mathrm{~h}$ using an atomic force microscope are presented in Fig. 1.

As follows from Fig. 1, the structure (morphology and topography) of the surface of composite materials depends on the concentration of the chalk additive. The effect of UV radiation on the samples with the addition of chalk for $18 \mathrm{~h}$ leads to a decrease in the mean square roughness by 3 times and the maximum surface height by $2-3$ times - based on a comparison of the data in Table 2. The surface relief is smoothed, namely, the bands disappear. Processing for $36 \mathrm{~h}$ leads to a new increase in irregularities compared with irradiation of $18 \mathrm{~h}$. But at the same time, the irregularities have a completely different character, apparently related to the appearance of depressions in separate parts of the surface (the destruction effect).

Thus, from the AFM images of the samples subjected to ultraviolet irradiation for $18 \mathrm{~h}$, it is seen that the surface becomes smoother. This is confirmed by the calculations of the root mean square roughness and the maximum height of the roughness. Further irradiation for additional $18 \mathrm{~h}$ leads to an increase in roughness, but the initial values are not reached. Surface treatment for $36 \mathrm{~h}$ in all cases leads to the appearance of small dark areas of a spherical shape

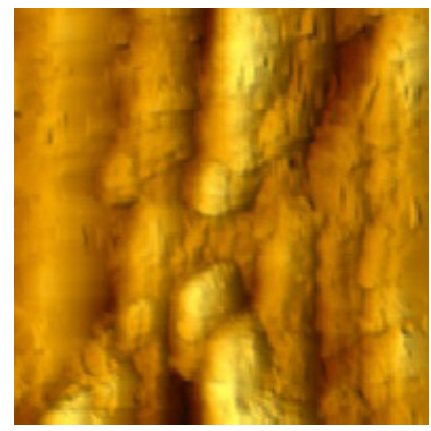

a

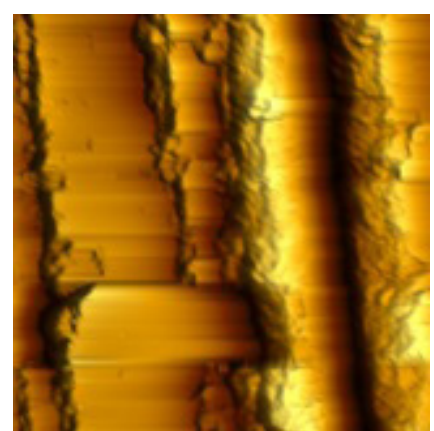

d

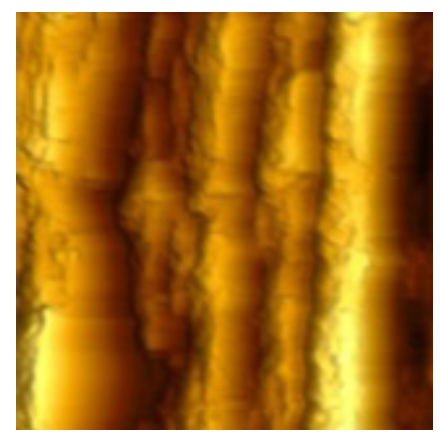

$\mathrm{g}$

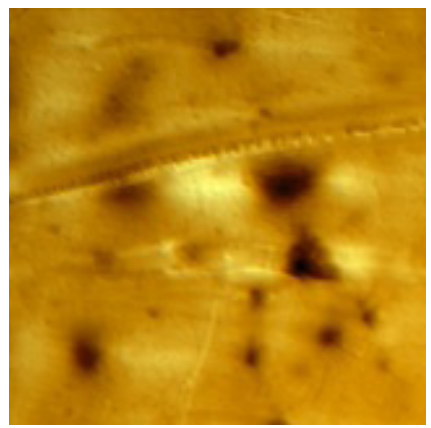

$\mathrm{b}$

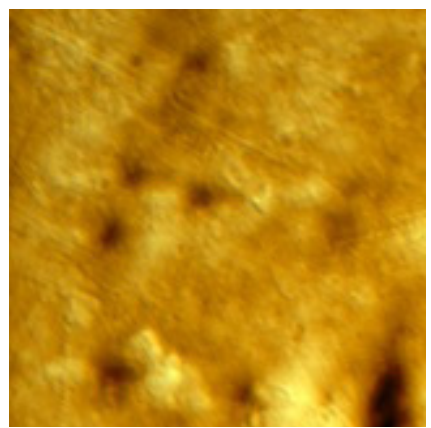

$\mathrm{e}$

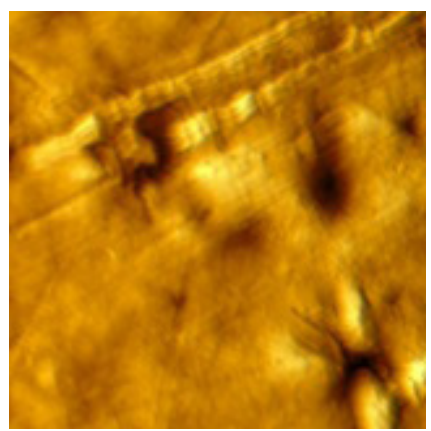

$\mathrm{h}$

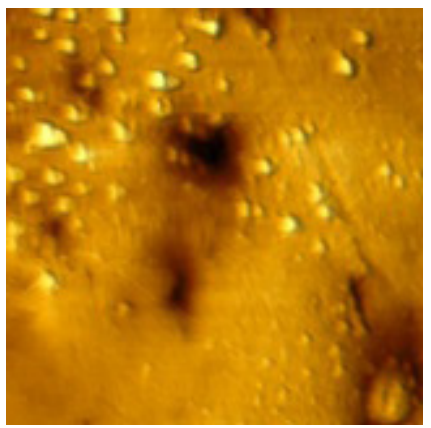

C

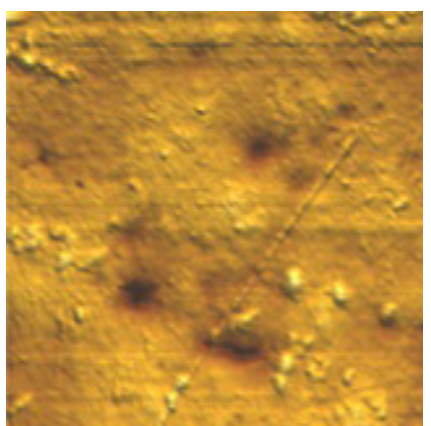

f

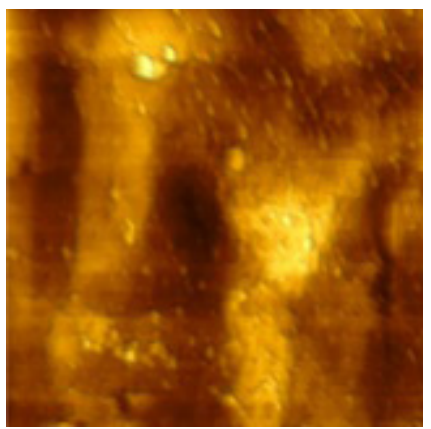

i

Fig. 1. (Color online) The surface morphology of the composite based on secondary PP and $2(a-c), 5$ (d-f) and 10 wt.pts. chalk additives $(\mathrm{g}-\mathrm{i})$ : before $(\mathrm{a}, \mathrm{d}, \mathrm{g})$ and after $18(\mathrm{~b}, \mathrm{e}, \mathrm{h})$ and 36 hours $(\mathrm{c}, \mathrm{f}, \mathrm{i})$ UV irradiation. 
due to enhanced photodestruction of local areas. Still, photooxidative transformations affect the change in the supramolecular structure of the surface layers of composites based on recycled PP, despite the presence of a chalk additive.

Thus, the effect of UV radiation leads to a change in the surface relief of polymer composites, as well as the formation of new polar centers, which can affect their deformationstrength properties [16]. In this regard, we studied the changes in the physic mechanical properties (elastic modulus, tensile stress) of composites based on recycled PP filled with chalk, exposed to UV radiation in air. Generalizing dependences are presented in Figs. 2,3. It is seen that for all mixed compositions, the nature of the dependences of the elastic modulus and breaking stress on the ratio of components after exposure to UV radiation is similar to such dependences for unmodified samples, and the change in physic mechanical properties is generally insignificant.

These facts can be explained by two reasons. Firstly, the processes of photo-oxidative degradation of PP under the influence of UV radiation in air are accompanied by cross linking of macromolecules due to the intermolecular interaction of hydro peroxide groups accumulated by the polymer. Second, photo oxidative transformations under the studied conditions affect only the surface layers of composite samples and do not affect the properties of materials in bulk [7].

\section{Summary}

It was found that the chalk additive slightly reduces the intensity of the occurrence of photo-oxidative transformations under the influence of UV radiation in air in composite materials based on secondary polypropylene.

The effect of UV radiation on samples of composites based on recycled PP with the addition of chalk for $18 \mathrm{~h}$ leads to a decrease in the root mean square roughness. In this case, the surface relief is smoothed, namely, the bands disappear. Processing for $36 \mathrm{~h}$ leads to a new increase in irregularities compared with irradiation lasting $18 \mathrm{~h}$. But at the same time, the irregularities have a different character, apparently related to a change in the supramolecular structure in the surface layers of polypropylene as a result of photooxidative transformations.

In general, the introduction of a chalk additive in a small amount $(2-10 \mathrm{wt}$. pts.) allows you to keep the strength properties of composites based on recycled polypropylene raw materials practically unchanged after exposure to UV radiation in air.

Consequently, from the obtained composites, one can expect the maintenance of operational characteristics during the period of consumption, followed by decomposition under the influence of environmental factors.

Table 2. Quantitative characteristics of the surface structure of samples of composite materials based on recycled PP in the presence of chalk additives after exposure to UV radiation in air for $18 \mathrm{~h}$ and $36 \mathrm{~h}$.

\begin{tabular}{|c|c|c|c|c|c|c|}
\hline \multirow{3}{*}{$\begin{array}{c}\text { The content of } \\
\text { chalk additives, } \\
\text { wt.pts. }\end{array}$} & \multicolumn{3}{|c|}{$\mathrm{RMS}$ roughness, $\mathrm{nm}$} & \multicolumn{3}{|c|}{ The maximum height of roughness, $\mathrm{nm}$} \\
\hline & \multirow{2}{*}{$\begin{array}{l}\text { before UV } \\
\text { treatment }\end{array}$} & \multicolumn{2}{|c|}{ after treatment } & \multirow{2}{*}{$\begin{array}{l}\text { before UV } \\
\text { treatment }\end{array}$} & \multicolumn{2}{|c|}{ after treatment } \\
\hline & & $18 \mathrm{~h}$ & $36 \mathrm{~h}$ & & $18 \mathrm{~h}$ & $36 \mathrm{~h}$ \\
\hline 2 & 73 & 24 & 58 & 359 & 109 & 227 \\
\hline 5 & 124 & 45 & 49 & 550 & 232 & 218 \\
\hline 10 & 150 & 51 & 90 & 630 & 255 & 458 \\
\hline
\end{tabular}

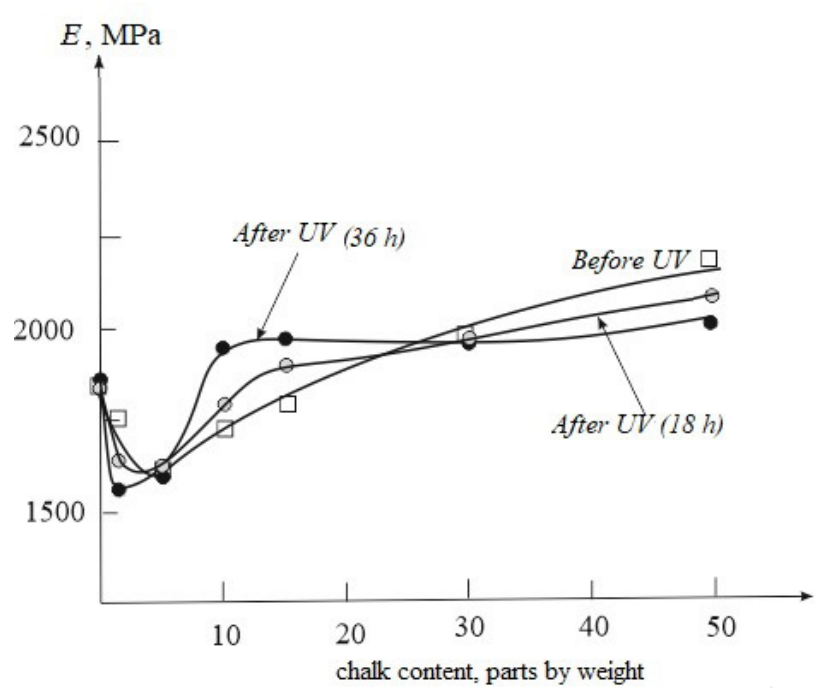

Fig. 2. The dependence of the elastic modulus of composites based on recycled PP and chalk on the chalk content before and after exposure to UV radiation in air at $45^{\circ} \mathrm{C}$.

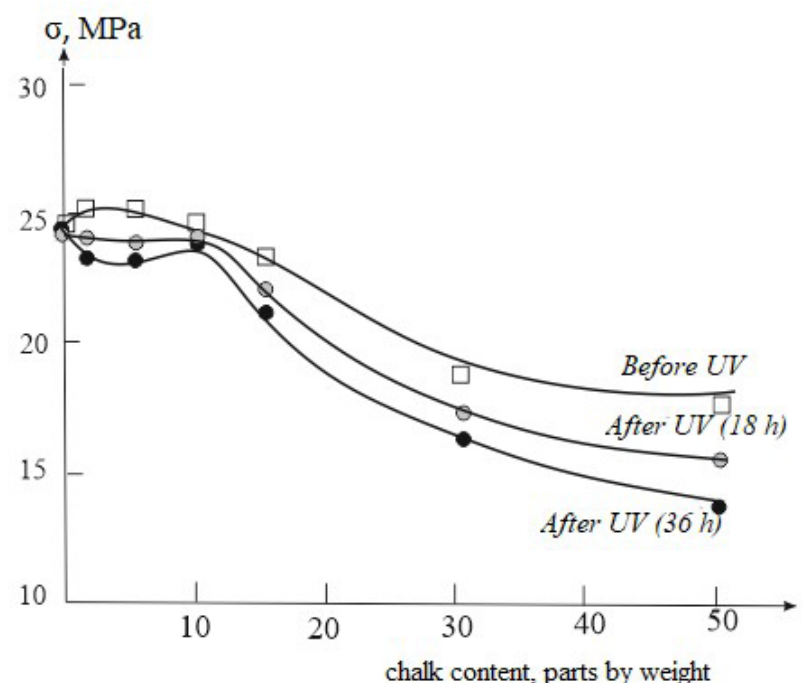

Fig. 3. The dependence of the breaking stress on the basis of recycled PP and chalk on the chalk content before and after exposure to UV radiation in air at $45^{\circ} \mathrm{C}$. 


\section{References}

1. A. A.Shah, F. Hasan, A. Hameed, S. Ahmed. Biotechnology Advances. 26, 246 (2008). Crossref

2. S.Z. Rogovina. Polymer Science, Series C. 58, 62 (2016). Crossref

3. S. Mühl, B. Beyer. Electronics. 3 (3), 444 (2014). Crossref

4. R.B. Salikhov, Y.N. Biglova, Y.M. Yumaguzin, T. R. Salikhov, M.S. Miftakhov, A. G. Mustafin. Technical Physics Letters. 39, 854 (2013). Crossref

5. A.A. Bunakov, R. B. Salikhov, A. N. Lachinov. Technical Physics. 48, 626 (2003). Crossref

6. Yu. N. Pankova, A.N. Shchegolikhin, A.L. Iordanskii, A. L. Zhulkina, A. A. Ol'khov, G.E. Zaikov. Journal of Molecular Liquids. 156 (1), 65 (2010). Crossref

7. M.V. Bazunova, A.R. Sadritdinov, R.A. Mustakimov, E.I. Kulish, V.P. Zakharov. Promising materials. 7, 42 (2019). (in Russian) [М. В. Базунова, А. Р. Садритдинов, Р.А. Мустакимов, Е.И. Кулиш, В.П. Захаров. Перспективные материалы. 7, 42 (2019).] Crossref

8. V. Ya. Shlyapintokh. Photochemical transformations and stabilization of polymers. Moscow, Khimiya (1979) 344 p. (in Russian) [В.Я. Шляпинтох. Фотохимические превращения и стабилизация полимеров. Москва, Химия (1979) 344 с.]

9. M.V. Bazunova, R.A. Mustakimov, A.R. Sadritdinov, E.I. Kulish, V.P. Zakharov. Bulletin of the Bashkir University. 24, 49 (2019). (in Russian) [М. В. Базунова, А.Р. Садритдинов, Р.А. Мустакимов, Е.И. Кулиш, В.П. Захаров. Вестник Башкирского университета. 24 (1), 49 (2019).] Crossref
10. A.A. Berlin, S.A. Wolfson, V.G. Oshmyan, N.S. Enikolopov. The principles of composite polymer materialscreating. Moscow, Khimiya (1990) 237 p. (in Russian) [А.А. Берлин, С.А. Вольфсон, В.Г. Ошмян, Н.С. Ениколопов. Принципы создания композиционных полимерных материалов. Москва, Химия (1990) 237 с.]

11. A. B. Baranov, I.D. Simonov-Emelyanov, T.I. Andreeva. Plastics. (3-4), 4 (2020). (in Russian) [А.Б. Баранов, И.Д. Симонов-Емельянов, Т.И. Андреева. Пластические массы. (3-4), 4 (2020).] Crossref

12. E. Yu. Shits, V.V. Koryakina. Promising materials. 4, 53 (2012). (in Russian) [Е. Ю. Шиц, В.В.Корякина. Перспективные материалы. 4, 53 (2012).]

13. A.S. Kolosova, M.K. Sokolskaya, I. A. Vitkalova, A.S. Torlova, E.S. Pikalov. International Journal of Applied and Basic Research. 8, 123 (2018). (in Russian) [А.С. Колосова, М.К. Сокольская, И.А. Виткалова, А. С. Торлова, Е. С. Пикалов. Международный журнал прикладных и фундаментальных исследований. 8, 123 (2018).]

14. A.E. Raskutin. Aviation materials and technologies. 5, 344 (2017). (in Russian) [А. Е. Раскутин. Авиационные материалы и технологии. 5, 344 (2017).] Crossref

15. D.V. Kuznetsov, I.A. Ilinykh, V.V. Cherdyntsev, D.S. Muratov, N.V. Shatrova, I.N. Burmistrov. Modern problems of science and education. 6 (2012). (in Russian) [Д.В. Кузнецов, И.А. Ильиных, В.В. Чердынцев, Д.С. Муратов, Н.В. Шатрова, И.Н. Бурмистров. Современные проблемы науки и образования. 6 (2012).]

16. D. G. Dikobe, A.S. Luyt. Thermochimica Acta. 654, 40 (2017). Crossref 